\title{
Incidence of Insect Pest of Pomegranate in Banaskantha during Mrig Bahar
}

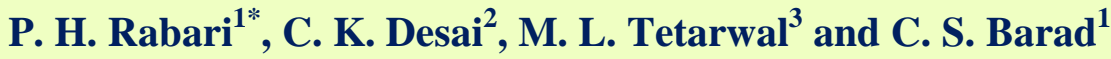 \\ ${ }^{1}$ Department of Entomology, ${ }^{3}$ Department of Plant Pathology, \\ C. P. College of Agriculture, S. D. Agricultural University, Sardarkrushinagar, India \\ ${ }^{2}$ Krushi Vigyan Kendra, S. D. Agricultural University, Tharad, India \\ *Corresponding author
}

\section{A B S T R A C T}

Ke y w o r d s
Pomegranate,
Thrips, Anar
butterfly, Fruit
sucking moth

Survey was conducted in major pomegranate growing area of Tharad, Deodar and Bhabhar talukas of Banaskantha district in Gujarat during mrig bahar season by using of multistage ramdom methods. Population of anar butterfly, fruit suckin moth, thrips, whitefly and aphid was observed during the period of study. The average maximum damage of Anar butterfly and Fruit sucking moth was recorded around $0.93 \%$ and $0.62 \%$, respectively in Bhabhar talukas, and that of only 0.53 $\%$ and $0.18 \%$ in Deodar and Tharad talukas during mrig bahar. The average highest population of thrips was recorded around 4.10 per shoot in Bhabhar talukas and that of only 2.59 per shoot in Tharad talukas during mrig bahar. Very few population of whitefly and aphid was also observed and they may became major pest in future.

\section{Introduction}

Pomegranate (Punica granatum L.) is one of the most adaptable subtropical minor fruit crops, commonly known as anar, dalim or dalimbe. It belongs to one of the smallest families of plant kingdom, Punicaceae. Pomegranate is native to Iran, where it was first cultivated around $2000 \mathrm{BC}$ and spread to the Mediterranean countries that observed by Evereinoff, in 1949. It is extensively cultivated in Spain, Morocco, Egypt, Iran, Afghanistan, Arabia and Baluchistan. Its cultivation spread further to other countries like China, Japan, USA, USSR, Pakistan and
India. During 1986, Bose observed that the area under pomegranate cultivation in India was increased due to the introduction of high yielding soft seeded variety "Ganesh" in the states of Maharashtra, Karnataka and Gujarat. Pomegranate is grown in tropical and subtropical regions of the world. Maharashtra is the leading producer of pomegranate followed by Karnataka, Andhra Pradesh, Gujarat and Tamil Nadu. Ganesh, Bhagwa, Ruby, Arakta and Mridula are the different varieties of pomegranates grown in different states of the country Andhra Pradesh and Tamil Nadu. The demand for export quality pomegranate certainly shows an increasing 
trend. In order to maintain good quality yield of pomegranate fruits, appropriate package of practices plays important role, in which pest control based on seasonal incidence, critical monitoring of pest stages with their intensity and execution of selected control measures is of high significance. There are three main fruiting seasons in a year which are localy known as bahars viz. Ambia (March to June), Mrig (July to October) and Hasta (November to February). This situation is therefore most favorable to perpetuate the pests throughout the year.

Cultivation of high yielding varieties of pomegranate with intensive care and management in the recent past under irrigated condition with early stage exploitation of plant has lead to certain severe pest problems. Among them, infestation by sucking pests like aphids, thrips and whiteflies results in reduction of pomegranate fruit yield and put the growers into hardship. The growers loose in terms of quantity and quality of fruits also.

The major constraint in increasing export potential is the quality of fruit in terms of size, colour, freedom from blemishes and pesticide residue levels. Anar butterfly, bark eating caterpillar and sucking pests (aphids \& thrips) are the most common pests damaging this crop in Gujarat. Now a days, fruit sucking moth is a new threat damaging the fruits of pomegranate next to cotton. Gilbert (1986) reported that thrips, Scirtothrips dorsalis (H.) is one of the most important pests infesting pomegranate crop. It feeds on the foliage as well as fruits deteriorating quality of the fruits. At International level thrips are considered as a potential pest in pomegranate being responsible for deteriorating quality of the fruits (Wang, 1994). Therefore, the present study was designed to know the extent of damage of insect pests in pomegranate for effective management measures there by.

\section{Materials and Methods}

Investigation was undertaken to study the incidence of major insect pests of pomegranate in different villages of banaskantha districts during mrig bahar.

Survey: Surveys was conducted in major pomegranate growing area of Tharad, Deodar and Bhabhar talukas of Banaskantha district in Gujarat during mrig bahar by using of multistage ramdom method. For this, two villages of each taluka's having maximum area was selected for the study. In each village, five pomegranate orchards owned by the farmers were randomly selected. In each orchard, five pomegranate plants was selected randomly and marked for taking observation on the incidence of insect pests.

Insect pests: The insect pests infest pomegranate was recorded on the selected plants at fortnight interval. Observations on the incidence of sucking insect pests were recorded on the five new shoots of each plant. Observations on fruit damaging insect pests were done by counting of number of damaged fruits out of total fruits/ plant during mrig bahar crop.

\section{Results and Discussion}

Survey was conducted at fortnight interval in Tharad, Bhabhar and Deodar taluka of Banaskantha district during 2017 and 2018. Table 1 revealed that the average maximum damage of anar butterfly and fruit sucking moth was recorded around $1.17 \%$ and 0.50 $\%$, respectively in Tharad and Bhabhar talukas, and that of only $1.03 \%$ and $0.38 \%$ in Deodar and Tharad talukas during mrig bahar 2017. Whereas, the average maximum damage of anar butterfly and fruit sucking moth was recorded around $0.93 \%$ and 0.62 $\%$, respectively in Bhabhar talukas, and that of only $0.53 \%$ and $0.18 \%$ in Deodar and 
Tharad talukas during mrig bahar 2018. The damage of anar butterfly reaches maximum during October and November whereas, damage of fruit sucking moth reaches maximum during October and November also. Based on two year, overall population of anar butterfly during mrig bahar 2017 was $1.12 \%$, however it was $0.68 \%$ during mrig bahar 2018.

Table.1 Survey of anar butterfly and fruit sucking moth of pomegranate on farmers' field during mrig bahar

\begin{tabular}{|c|c|c|c|c|c|}
\hline \multicolumn{2}{|c|}{ Place } & \multicolumn{4}{|c|}{ Percent Damage } \\
\hline \multirow[t]{2}{*}{ Taluka } & \multirow[t]{2}{*}{ Village } & \multicolumn{2}{|c|}{ Anar butterfly } & \multicolumn{2}{|c|}{ Fruit sucking moth } \\
\hline & & 2017 & 2018 & 2017 & 2018 \\
\hline \multirow[t]{2}{*}{ Tharad } & Vadgamda & 1.15 & 0.47 & 0.39 & 0.12 \\
\hline & Bhapi & 1.19 & 0.69 & 0.38 & 0.24 \\
\hline \multicolumn{2}{|c|}{ Average of Tharad } & 1.17 & 0.58 & 0.38 & 0.18 \\
\hline \multirow[t]{2}{*}{ Deodar } & Liladhar & 0.95 & 0.45 & 0.45 & 0.48 \\
\hline & Bhesana & 1.11 & 0.60 & 0.51 & 0.43 \\
\hline \multicolumn{2}{|c|}{ Average of Deodar } & 1.03 & 0.53 & 0.48 & 0.46 \\
\hline \multirow[t]{2}{*}{ Bhabhar } & Jasanwada & 1.18 & 0.90 & 0.49 & 0.59 \\
\hline & Devkapdi & 1.15 & 0.97 & 0.51 & 0.65 \\
\hline \multicolumn{2}{|c|}{ Average of Bhabhar } & 1.16 & 0.93 & 0.50 & 0.62 \\
\hline \multicolumn{2}{|l|}{ Average } & 1.12 & 0.68 & 0.45 & 0.42 \\
\hline
\end{tabular}

Table.2 Survey of sucking pests of pomegranate on farmers' field during mrig bahar

\begin{tabular}{|l|c|c|c|c|c|c|c|}
\hline \multicolumn{2}{|c|}{ Place } & \multicolumn{7}{c|}{ No. of insect per shoot } \\
\hline \multicolumn{1}{|c|}{ Taluka } & Village & \multicolumn{2}{|c}{ Thrips } & \multicolumn{2}{c|}{ Whitefly } & \multicolumn{2}{c|}{ Aphid } \\
\cline { 3 - 10 } & & $\mathbf{2 0 1 7}$ & $\mathbf{2 0 1 8}$ & $\mathbf{2 0 1 7}$ & $\mathbf{2 0 1 8}$ & $\mathbf{2 0 1 7}$ & $\mathbf{2 0 1 8}$ \\
\hline \multirow{2}{*}{ Tharad } & Vadgamda & 2.87 & 2.68 & 0.09 & 0.08 & 0.07 & 0.14 \\
\hline & Bhapi & 2.63 & 2.51 & 0.08 & 0.06 & 0.08 & 0.11 \\
\hline \multirow{2}{*}{ Average of Tharad } & $\mathbf{2 . 7 5}$ & $\mathbf{2 . 5 9}$ & $\mathbf{0 . 0 9}$ & $\mathbf{0 . 0 7}$ & $\mathbf{0 . 0 8}$ & $\mathbf{0 . 1 3}$ \\
\hline Deodar & Liladhar & 2.47 & 3.22 & 0.04 & 0.00 & 0.11 & 0.00 \\
\cline { 2 - 9 } & Bhesana & 2.81 & 3.51 & 0.03 & 0.00 & 0.06 & 0.07 \\
\hline Average of Deodar & $\mathbf{2 . 6 4}$ & $\mathbf{3 . 3 6}$ & $\mathbf{0 . 0 3}$ & $\mathbf{0 . 0 0}$ & $\mathbf{0 . 0 9}$ & $\mathbf{0 . 0 4}$ \\
\hline Bhabhar & Jasanwada & 3.21 & 3.98 & 0.03 & 0.09 & 0.24 & 0.28 \\
\hline & Devkapdi & 3.40 & 4.23 & 0.02 & 0.07 & 0.28 & 0.35 \\
\hline Average of Bhabhar & $\mathbf{3 . 3 0}$ & $\mathbf{4 . 1 0}$ & $\mathbf{0 . 0 3}$ & $\mathbf{0 . 0 8}$ & $\mathbf{0 . 2 6}$ & $\mathbf{0 . 3 2}$ \\
\hline Average & $\mathbf{2 . 9 0}$ & $\mathbf{3 . 3 5}$ & $\mathbf{0 . 0 5}$ & $\mathbf{0 . 0 5}$ & $\mathbf{0 . 1 7}$ & $\mathbf{0 . 1 6}$ \\
\hline
\end{tabular}

The population of fruit sucking moth was 0.45 $\%$ and $0.42 \%$ during mrig bahar in the year 2017 and 2018, respectively. Mote (1991) recorded that damage to fruits reached a maximum of $57 \%$ and up to 9 holes/fruit in Maharashtra. Anitha Kumari (2011) was conducted survey during 2006-2008 to investigate the population dynamics of major pests of pomegranate and observed that major pests on vegetative parts were stem borer and while fruit borer recorded on reproductive parts. Fruit borer Deudorix isocrates (Fabricius) is the 
major pest which is constantly and regularly injurious in pomegranate during flowering and fruit set stage. Oviposition was observed on calyx and young larvae damage the fruits from fruit set to maturity stage. The incidence of fruit borer was maximum during monsoon season (mrig bahar crop). Low temperatures coupled with high humidity were congenial for the development of borer during the second fortnight of August.

The population of sucking pest viz., thrips, aphid and whitefly was observed. Among them highest population of thrips was observed. Table 2 revealed that the average highest population of thrips was recorded around 3.30 per shoot in Bhabhar talukas and that of only 2.64 per shoot in deodar talukas during mrig bahar 2017. Whereas, the average highest population of thrips was recorded 4.10 per shoot in Bhabhar talukas and that of only 2.59 per shoot in tharad talukas during mrig bahar 2018 . The population of thrips reaches maximum during October and November. Very few population of whitefly and aphid was also observed and they may became major pest in future. Based on two year, the population of thrips was 2.90 and 3.35 per shoot during mrig bahar in the year 2017 and 2018, respectively. Anitha Kumari (2011) was conducted survey during 2006-2008 to investigate the population dynamics of major pests of pomegranate and observed that major pests on vegetative parts were aphids, thrips, mites and mealy bugs recorded on reproductive parts. Incidence of thrips was observed on new flush but its severity was less. Aphids infestation was noticed on new flush as well as small fruits and the infestation was severe during August to September months. Moreover, Ananda (2009) suggested that the aphid population on pomegranate initiated at $48 \mathrm{MW}$ and raised slowly upto $52 \mathrm{MW}$ and steadily upto $6 \mathrm{MW}$ and maximum at about $8 \mathrm{MW}$. The maximum incidence of aphids on pomegranate was observed during third week of Feb and March in Tamil Nadu (Karuppunchamy et al., 1998).

\section{References}

Ananda, N., Kotikal, Y.K. and Balikai, R. A. (2009). Management practices for major sucking pests of pomegranate. Karnataka J. Agric. Sci., 22(4):790-795.

Anitha Kumari, D., Lakshmi, B.K.M., Suresh Kumar, T. and Satyanarayana Reddy, G. (2011). Population dynamics of major pests of pomegranate in central telagangana zone of andhra pradesh. Acta Hortic. 890, 585-588 DOI: 10.17660/ ActaHortic. 2011.890.82.

Bose, T.K. (1986). Fruits of India, tropical and sub-tropical Nayaprakash, Calcutta, India, 636.

Gilbert, M.J. (1986). First African record of $S$. Dorsalis (Thysanoptera: Thripidae) a potential pest of citrus and other crops. $J$ Ent. S. Africa. 49(11): 159-161.

Karuppuchamy, P., Balasubramanian, G. and Sundarababu, P. C. (1998). Seasonal incidence and management of aphid, Aphis punicae on pomegranate. Madras Agric. J. 85(5-6):224-226.

Mote, U.N., Tambe, A.B. and Patil, C.S. (1991). Observations on incidence and extent of damage of fruit sucking moths on pomegranate fruits. Journal of Maharashtra Agricultural Universities. 16(3): 438-439.

Wang, C.L. (1994). The species of genus Scirtothrips of Taiwan. J. Taiwan Museum. 47(2): 1-7.

\section{How to cite this article:}

Rabari, P. H., C. K. Desai, M. L. Tetarwal and Barad, C. S. 2020. Incidence of Insect Pest of Pomegranate in Banaskantha during Mrig Bahar. Int.J.Curr.Microbiol.App.Sci. 9(09): 1874-1877. doi: https://doi.org/10.20546/ijcmas.2020.909.236 